\title{
Between-school inequalities in access to STEM curricula in a marketized education system: The case of Australia
}

\author{
Laura B. Perry ${ }^{\mathrm{a} *}$, Christopher Lubienski ${ }^{\mathrm{b}}$, and Philip Roberts ${ }^{\mathrm{c}}$ \\ ${ }^{a}$ Education Discipline, Murdoch University, Perth, Australia; ${ }^{b}$ Department of Educational \\ Leadership and Policy Studies, Indiana University, Bloomington, USA; ${ }^{c}$ Faculty of \\ Education, University of Canberra, Canberra, Australia
}

*corresponding author: 1.perry@murdoch.edu.au

Laura B. Perry is Professor of comparative education, sociology of education, and education policy at Murdoch University. She conducts research about educational disadvantage and inequalities, especially as they appear between schools, and the systems, structures and policies that shape them. The aim of her research is to inform policy and practice for improving equity of educational opportunities, experiences and outcomes. Specific research interests include educational marketization, school segregation and stratification, and social class and education. ORCID 00000003-4252-2379.

Christopher Lubienski is a Professor of education policy at Indiana University. He is also a fellow with the National Education Policy Center at the University of Colorado, Visiting Professor at East China Normal University in Shanghai, and was previously Sir Walter Murdoch Visiting Professor at Murdoch University in Western Australia. His research focuses on education policy, reform, and the political economy of education, with a particular concern for issues of equity and access. His current work examines (1) organizational responses to competitive conditions in local education markets, including geo-spatial analyses education opportunities, and research on innovation in education markets for the OECD, and (2) policymakers' use of research evidence as influenced by advocacy organizations. ORCID 0000-0001-7372-5801.

Philip Roberts is Associate Professor of curriculum inquiry and rural education at the University of Canberra. His major ongoing research focuses on the role of knowledge in curriculum, rural knowledges and the sustainability of rural communities. He currently holds an Australian Research Council Discovery Early Career Research Award (DECRA) 2020-2022. ORCID 0000-0001-73351854 


\begin{abstract}
Increasing the number of students who study science and math is a priority in many countries, but between-school inequalities in the opportunity to learn these subjects is not well understood. We examine stratified opportunities to learn science and math subjects in upper secondary schools in Australia, as a case study for developing a theoretical framework about access to curricular subjects in comprehensive education systems. We found that biology and chemistry are offered in most schools but substantial inequalities exist in access to physics and especially advanced mathematics. School size, school socioeconomic composition, school sector and school location (rural/urban) predict whether a school offers advanced mathematics. The findings suggest that access to science and math subjects is far from universal even in a prosperous country with a comprehensive secondary education system. We conclude by presenting a theoretical framework for guiding future research about the factors that shape between-school curricular inequalities.
\end{abstract}

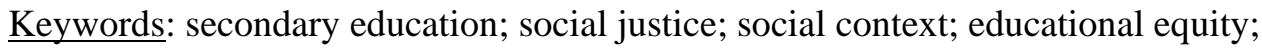
opportunity to learn; curriculum; STEM education

\title{
Introduction
}

Many national governments are seeking to increase the number of high school students that study science and maths as part of larger strategies to promote innovation and develop their knowledge economies (Marginson et al., 2013). Science and maths subjects provide important pathways for further study and stable and rewarding employment. Regardless of educational or career aspirations, a solid foundation in maths and science is important for all citizens. Without this knowledge, it is difficult to negotiate the myriad opportunities and challenges that are part of daily life. For societies, a scientifically literate citizenry is essential for helping solve many important social problems. Thus, scientific literacy and core disciplinary knowledge provide important benefits for both individuals and the larger society. Our basic premise, therefore, is that all students should have an opportunity to learn science and math subjects, regardless of where they go to school. 
While increasing student interest and motivation to study these subjects is important, we agree with Smyth and Hannan (2006) that it is also crucial to identify systemic barriers that may be preventing students from enrolling in science and maths subjects. It is unrealistic to expect large numbers of secondary students to study physics and advanced mathematics ${ }^{1}$, for example, if these subjects are not widely offered in schools. Between-school inequalities in access to science and maths curricula have not been examined extensively, perhaps due to the assumption that these subjects are available in all schools in comprehensive education systems.

In this study we examine access to science and maths subjects at upper secondary level in all schools in one Australian state. Our research questions are as follows:

- What proportions of secondary schools offer advanced mathematics, physics, chemistry and biology?

- Does the provision of these four curricular subjects vary by school socio-economic composition, school sector, or school location?

- Which school characteristics predict access to curricula?

Examining opportunities to study math and science subjects in Australian secondary schools can contribute to the development of a theoretical framework about the contexts and conditions that mediate access to these subjects in comprehensive education systems. The features of Australian schooling that may be theoretically relevant are as follows. It is a prosperous country with a high level of social and economic development, without the high levels of poverty and inequality that Berliner (2014) has shown are associated with diminished educational opportunities and outcomes. Its labour market consistently suffers

\footnotetext{
${ }^{1}$ We use "advanced mathematics" and calculus interchangeably throughout the text. Specialist Mathematics is the name of the most advanced mathematics curricular offering in Australian high schools, and is the object of our analyses.
} 
shortages of professions in the STEM fields. It has a comprehensive education system (i.e., a system in which most or all schools serve students of varying abilities and do not select students based on academic performance), which theoretically at least has the capacity to offer core academic curricula to an unlimited number of students. And unlike some countries such as the US, large funding disparities do not exist between Australian public schools. These features suggest that Australia has the capacity and demand to support science and math curricular offerings in all secondary schools. On the other hand, Australian schooling is not immune to structural inequality. Large funding disparities exist between many public and private schools, and more than $40 \%$ of students attend a private school in Australia (ABS, 2018). Compared to other economically developed countries, Australian schools are highly segregated by socioeconomic status, accompanied by large inequalities in human, financial and instructional resources (OECD, 2019). These inequalities are associated with high levels of marketization. Australian schooling is also highly marketized, with

Our findings contribute to an emerging body of research about between-school inequalities in curricular offerings in comprehensive education systems. As the field is developing, our findings may be useful for deepening theory about opportunity to learn science and maths curricula around the globe and the contexts, structures and policies that shape it. Our findings may also be useful for policymakers who are seeking to increase student participation in these subjects. Finally, our findings may contribute to the role of educational marketization in shaping curricular inequalities.

Our article is structured as follows. First we review the literature about opportunity to learn maths and science subjects in high school. We then describe the Australian educational context so that our findings can be interpreted for an international audience and, even more importantly, can be used to develop theory about the contexts, structures and policies that shape access to science and math curricula. We describe our method and present the findings, 
and then discuss the findings and their contribution to a larger theoretical framework about access to science and maths curricula in comprehensive education systems.

\section{Participation rates and opportunity to learn STEM subjects}

Researchers and policymakers around the world have been concerned about low participation rates of secondary students in science and maths subjects. These studies come from a range of national contexts, including Australia (Kennedy et al., 2014), Denmark (Jørgensen, 1998), Ireland (Drury \& Allen, 2002), the UK (Smith, 2011) and the US (National Research Council, 2010). As noted by Marginson et al. (2013), increasing the number of students who study science and maths subjects in secondary school is a government priority in most OECD countries.

Student participation rates in science and advanced mathematics have been examined in a range of national contexts. In Australia, 52\% of all students in the final year of secondary school study a science subject (Goodrum et al., 2012) and $72 \%$ study a mathematics subject (Barrington, 2011). Approximately one half of the students who are studying mathematics are enrolled in a basic course, $14 \%$ are enrolled in an intermediate course and $7 \%$ are enrolled in an advanced course (Barrington, 2011). These participation rates in advanced mathematics are lower than in some other countries. For example, the proportion of secondary students who study advanced mathematics is $14 \%$ in Finland (Marginson et al., 2013) and 18\% in the US (Anderson \& Chang, 2011).

Secondary school student participation rates in science and math subjects are patterned by ascriptive individual characteristics such as gender, race/ethnicity and socioeconomic status. Girls are less likely than boys to study advanced mathematics and physics (Jones et al., 2000; Sadler et al., 2012). Similarly, students from lower socioeconomic backgrounds are less likely than their more advantaged peers to study advanced 
mathematics and the natural sciences. This has been found in many (if not most) countries around the world, including Australia (Teese \& Lamb, 2007), England (Archer et al., 2017) and the US (Svoboda et al., 2016).

The factors that shape student participation in science and math offerings can be divided into two categories: factors that relate to individual students and their motivations and interests, and structural factors that relate to schools and education systems. Most of the literature falls into the first category. The research literature about students' interest and motivation to study science and maths subjects is extensive. For example, Wang and Degol (2013) reviewed more than 300 studies, the great majority of which concern student motivation and interest in science and maths subjects.

The main structural factor identified in the literature that shapes opportunities to learn science and math subjects is curricular differentiation and tracking practices within schools. Most high schools in English speaking countries practice within-school tracking (Chmielewski, 2014), where enrollment and/or acheivement in the earlier years of schooling is linked to study and achievement in the later years. Studies from the past 30 years and from a range of national contexts including Australia (Lamb \& Fullarton, 2002), the UK (Archer et al., 2017), and the US (Adelman, 2006; Oakes, 2005) have consistently shown that in schools with tracked maths and science offerings, students from lower socioeconomic backgrounds are less likely than their more advantaged peers to be enrolled in the most rigorous courses, such as calculus and physics. This finding has been found cross-nationally as well by Chmielewski (2014).

Another school-related factor that can influence participation rates is course availability. Students cannot study advanced mathematics or physics, for example, if it is not offered at their school. Somewhat surprisingly, this factor has not received much attention in the literature. A large number of studies have documented unequal participation rates by 
socioeconomic status, rurality and ethnicity/race and low overall participation rates more generally, but few have examined the proportions of students that attend a school that offers these courses. The little research that has been conducted about between-school stratification of opportunities to learn science and math subjects, however, is sobering. In the US, for example, Adelman (2006) found that the proportion of students who were in Year 12 in 1992 and that attended a high school that offered calculus varied widely by student SES. Among students in the lowest SES quintile, $44 \%$ attended a school that offered calculus, compared to $72 \%$ of students in the highest SES quintile (Adelman, 2006). Whether these striking between-school inequalities in the US in access to advanced mathematics have diminished in the last twenty-five years is not clear. In Ireland, small schools and schools with lower socioeconomic compositions are less likely to offer chemistry and physics than other schools (Smyth \& Hannan, 2006). School location is another structural factor linked to access to science and math subjects. In the Australian context, the Human Rights and Equal Opportunity Commission (2000) have noted the lack of access to science and math subjects in rural areas compared to metropolitan areas.

\section{The Australian educational context}

Australia has a comprehensive secondary education system, in which schools offer a range of academic and vocational curricula and enrol students with a diverse range of academic aptitudes and interests. Australia's national curriculum mandates the content and achievement standards for eight learning areas (two of which are Mathematics and Science). In the final two years of secondary school, science offerings become more specialised, comprising discrete disciplines, namely chemistry, physics, biology and earth/environmental science. The national curriculum framework for upper secondary mathematics is divided into four subjects of varying rigor (Essential Mathematics, General Mathematics, Mathematical 
Methods and Specialist Mathematics). Specialist Mathematics, the most advanced mathematics offering, is "designed for students with a strong interest in mathematics, including those intending to study mathematics, statistics, all sciences and associated fields, economics or engineering at university." (ACARA, n.d.).

In the final two years of secondary school, students choose from the range of curricular subjects that are offered at their school. Students who aspire to university education study four to six externally assessed academic subjects. The number of externally assessed subjects that are available to be offered in schools is very large, ranging from 80-125 subjects (depending on the jurisdiction). Unsurprisingly, no school offers all courses of study. On average, schools offer 10-25 externally assessed subjects, with the number of offered academic courses of study positively related to the size of the school and its socioeconomic composition (Perry \& Southwell, 2014). Schools choose which subjects to offer based on student demand, parent expectations and school resources, needs and profiles (Perry \& Lubienski, 2020).

Finally, we discuss the organisation and structure of Australian schooling. As schools with higher socioeconomic compositions are more likely to offer a larger number of academic subjects compared to schools with less advantaged student populations (Perry \& Southwell, 2014), we discuss the features of Australian schooling that are related to school socioeconomic composition. These features relate to school sector, school choice and competition, and school funding.

Australia has one of the largest private school sectors in the world, with $41 \%$ of all secondary school students attending a private school (ABS, 2018). The private sector comprises both parochial and non-sectarian schools and is divided into two categories: Catholic schools, which are administered by the Catholic Education Office (CEO) in each state, and independent schools (some of which are Catholic), which are not administered by 
the CEO or public authorities. The socioeconomic composition of schools is stratified by sector, with public schools having on average the lowest socioeconomic compositions and independent schools the highest (Connors \& McMorrow, 2015). Overall, Australian schooling is characterised by high levels of choice and competition, with schools competing for students within and between the three school sectors and many students attending a private or non-local public school. Public schools have catchment zones but may also enrol students, at their discretion, from other localities.

Sectoral stratification is related to Australia's complex school funding policy (Watson \& Ryan, 2010). Public schools in Australia receive most of their funding from state authorities, not local government authorities as in the US. As funding is allocated centrally, funding inequalities between public schools are much smaller compared to the US. In this sense, public school funding is similar in Australia to most countries in the world. Catholic and independent schools charge fees, ranging from a few thousand Australian dollars per year at some Catholic schools to $\$ 25,000$ AUD (approx. \$18k USD) or higher at elite independent schools. Private schools receive much of their funding from private sources (i.e., fees paid by families) but also receive public funding from state and federal governments. These public allocations are substantial, even for schools with high tuition fees. The funding formula in Australia has led to large cross sector resource disparities between schools, especially between high-fee private schools and all other schools.

In summary, Australian schooling has some unique characteristics that may mediate between-school inequalities in opportunities to learn science and maths subjects. These characteristics are summarised in Table 1 below. 
Table 1: Features of Australian schooling that may impact between-school inequalities in curricular access

Curriculum and assessment Organization and funding

- National curriculum standards with state interpretation and implementation

- $\quad$ Subject-specific, standardised exams that are externally assessed and provide the basis for school leaving certificates and university admissions

- Schools choose which externally assessed curricular subjects to offer
- Large proportion of students that attend fee-charging private schools

- High levels of school choice and competition

- High levels of school social segregation

- Substantial funding inequalities between schools

\section{Materials and methods}

We examined the extent to which four science and math subjects (Chemistry, Biology, Physics and Specialist Mathematics) are offered in the final year (Year 12) of all secondary schools in one Australian state (Victoria). As described earlier, Specialist Mathematics is the most advanced offering and is therefore comparable to advanced mathematics courses in other countries. We chose these four subjects because they are considered "core" science and math curricular subjects (Archer et al., 2017); they provide pathways to high-status professions including medicine and engineering; and except for Biology, they receive a favourable scaling in Australia's university admissions rank score, which can therefore influence admission to prestigious universities and courses of study (majors).

All schools in the state of Victoria that enrol students in the final year of secondary schooling were included in our study. Our census examination comprises 521 schools. Four "special schools" were excluded: one that uses distance learning for students who cannot attend school; and three alternative schools for students with severe learning impairments or behavioural problems, none of which offer academic curricular offerings. 
Victoria was chosen as a case study for both pragmatic and theoretical reasons. Pragmatically, Victoria was an ideal case because the curricular offerings of all its schools are publicly available on its curriculum authority website. Theoretically, Victoria is a suitable case study for examining access to science and maths subjects in Australia. It is Australia's most densely populated state and with more than six million residents, the second most populous state overall. Victoria is prosperous and enjoys a reputation for high educational standards, as evidenced by its nickname as the "The Education State". By choosing a populous and prosperous state for our study, we minimize the possibly confounding effects of high levels of social exclusion, poverty and geographic isolation.

We collected data from two publicly available government websites: the federal government's My School website for school characteristics and the Victorian Curriculum and Assessment Authority (VCAA) website for curricular offerings. The school characteristics include enrolment size, sector, location and socio-economic composition (i.e., school mean SES). We used school enrolment size, which is listed on My School, to estimate the number of students per year (grade).

My School uses five categories to denote school location: major cities, inner regional, outer regional, remote and very remote (https://www.myschool.edu.au/glossary/\#l). Our dataset includes 352 metropolitan (major cities) schools, 114 inner regional schools, 50 outer regional schools, 4 remote schools and 0 very remote schools; due to the small number of remote schools and for ease of reporting, we collapsed remote schools into the outer regional category. All of the metropolitan schools are located in the greater Melbourne metropolitan area. In addition, MySchool divides schools into two school sectors: government (public) and non-government (private). As is commonly reported in Australian research and as is reported on the VCAA website, we further divided non-government schools into "Catholic" or “independent". 
We used the Index of Community Socio-Educational Advantage (ICSEA), a measure developed by ACARA and included on My School, as a proxy for school socioeconomic status (SES). ICSEA is based on student characteristics (parental occupation and parental educational attainment) and school characteristics (proportion of Indigenous students and school location). ICSEA scores are scaled so that the national median is 1000 and a standard deviation is 100 . Scores range from a low of 500 (representing extreme disadvantage) to about 1300 (representing extreme advantage). The ICSEA values in our population range from 863 to 1203 .

Table 2 below shows the distribution of schools in our sample. School SES quintiles are ordered from a low SES (quintile 1) to high SES (quintile 5). The proportions of schools for each sector are shown within each school SES quintile. For example, $86 \%$ of low SES metropolitan schools are government schools, and 77\% of high SES schools are independent schools. The reported proportions do not always add up to $100 \%$ due to rounding.

(continued on following page) 
Table 2. Summary statistics of sample

\begin{tabular}{|c|c|c|c|c|c|}
\hline \multicolumn{6}{|c|}{ Metropolitan schools } \\
\hline $\begin{array}{l}\text { School SES } \\
\text { quintile }\end{array}$ & $\begin{array}{c}\text { Mean } \\
\text { number of } \\
\text { students } \\
\text { enrolled per } \\
\text { school } \\
\end{array}$ & $\begin{array}{c}\text { Gov } \\
\text { N (\%) }\end{array}$ & $\begin{array}{c}\text { Cath } \\
\mathbf{N}(\%)\end{array}$ & $\begin{array}{c}\text { Ind } \\
\mathbf{N}(\%)\end{array}$ & $\begin{array}{c}\text { Total number } \\
\text { of schools }\end{array}$ \\
\hline 1 (low) & 856 & $61(86 \%)$ & $7(9 \%)$ & $3(4 \%)$ & 71 \\
\hline 2 & 1054 & $53(76 \%)$ & $8(11 \%)$ & $9(13 \%)$ & 70 \\
\hline 3 & 908 & $23(33 \%)$ & $22(31 \%)$ & $25(36 \%)$ & 70 \\
\hline 4 & 1047 & $24(34 \%)$ & $17(24 \%)$ & $29(41 \%)$ & 70 \\
\hline 5 (high) & 1118 & $9(13 \%)$ & $7(10 \%)$ & $55(77 \%)$ & 71 \\
\hline Total & 1110 & $170(48 \%)$ & $61(17 \%)$ & $121(34 \%)$ & 352 \\
\hline \multicolumn{6}{|c|}{ Inner regional schools } \\
\hline $\begin{array}{c}\text { School SES } \\
\text { quintile }\end{array}$ & $\begin{array}{c}\text { Mean } \\
\text { number of } \\
\text { students }\end{array}$ & $\begin{array}{c}\text { Gov } \\
\mathbf{N}(\%)\end{array}$ & $\begin{array}{c}\text { Cath } \\
\text { N }(\%)\end{array}$ & $\begin{array}{c}\text { Ind } \\
\mathbf{N}(\%)\end{array}$ & $\begin{array}{c}\text { Total number } \\
\text { of schools }\end{array}$ \\
\hline 1 (low) & 574 & $22(96 \%)$ & $1(4 \%)$ & $0(0 \%)$ & 23 \\
\hline 2 & 562 & $22(100 \%)$ & $0(0 \%)$ & $0(0 \%)$ & 22 \\
\hline 3 & 537 & $18(78 \%)$ & $5(22 \%)$ & $0(0 \%)$ & 23 \\
\hline 4 & 590 & $5(22 \%)$ & $13(57 \%)$ & $5(22 \%)$ & 23 \\
\hline 5 (high) & 829 & $1(4 \%)$ & $6(26 \%)$ & $16(70 \%)$ & 23 \\
\hline Total & 616 & $68(60 \%)$ & $25(22 \%)$ & $21(18 \%)$ & 114 \\
\hline \multicolumn{6}{|c|}{ Outer regional / remote schools } \\
\hline $\begin{array}{c}\text { School SES } \\
\text { quintile }\end{array}$ & $\begin{array}{c}\text { Mean } \\
\text { number of } \\
\text { students }\end{array}$ & $\begin{array}{c}\text { Gov } \\
\text { N (\%) }\end{array}$ & $\begin{array}{c}\text { Cath } \\
\text { N (\%) }\end{array}$ & $\begin{array}{c}\text { Ind } \\
\mathbf{N}(\%)\end{array}$ & $\begin{array}{c}\text { Total number } \\
\text { of schools }\end{array}$ \\
\hline 1 (low) & 603 & $11(100 \%)$ & $0(0 \%)$ & $0(0 \%)$ & 11 \\
\hline 2 & 592 & $10(91 \%)$ & $1(9 \%)$ & $0(0 \%)$ & 11 \\
\hline 3 & 533 & $10(100 \%)$ & $0(0 \%)$ & $0(0 \%)$ & 10 \\
\hline 4 & 288 & $10(91 \%)$ & $1(9 \%)$ & $0(0 \%)$ & 11 \\
\hline 5 (high) & 542 & $7(64 \%)$ & $2(18 \%)$ & $2(18 \%)$ & 11 \\
\hline Total & 511 & $48(89 \%)$ & $4(7 \%)$ & $2(4 \%)$ & 54 \\
\hline Grand total & & $288(55 \%)$ & $90(17 \%)$ & $143(27 \%)$ & 521 \\
\hline
\end{tabular}

As shown in Table 2, government schools comprise just under half (48\%) of all metropolitan schools, $60 \%$ of inner regional schools, and $89 \%$ of outer regional / remote schools. Enrolment size is related to location and socioeconomic composition; on average, 
the largest schools are high SES schools in metropolitan areas. Finally, a clear pattern can be seen between school sector and school SES. In all three location categories, low SES schools are predominantly from the government sector, and high SES schools are predominantly from the independent sector.

Our analytical strategy comprises two approaches: descriptive statistics and a logistic regression. The descriptive statistics show the proportions of schools that offer the four curriculum subjects, disaggregated by school SES quintile, school sector, and location. This approach is simple but also easily accessible and powerful for uncovering inequalities. The logistic regression has the school as the unit of analysis, the dependent variable is whether the school offers Specialist Mathematics or not, and the independent variables include school year size, school sector (government, Catholic, independent), school socioeconomic composition (ICSEA score), and school location (metropolitan, inner regional, and outer regional / remote). We conducted the logistic regression for Specialist Mathematics since it was the only subject which was offered in less than $90 \%$ of schools in our census. Our aim with the logistic regression was to determine the relative strength of the predictor variables and their independent effects. We do not provide statistical comparisons of groups (e.g., between metropolitan and inner regional) or tests of statistical significance for any of the analyses since our dataset is a census population rather than a sample; inferential statistics are therefore not necessary.

\section{Results}

Our first analysis shows the proportion of schools, by school location, that offer each of the four subjects, as well as the total number of these four subjects offered. As shown in Table 3, Biology and Chemistry are almost universally offered in all schools; physics is offered in most metropolitan and inner regional schools, but not in $15 \%$ of outer regional 
schools. The provision of Specialist Maths, however, is very limited in all school location categories; the subject is offered in $71 \%$ of metropolitan schools, $48 \%$ of inner regional schools, and $22 \%$ of outer regional schools. Overall, $61 \%$ of schools in the state of Victoria offer Specialist Mathematics.

Table 3: Proportion of schools that offer the four science and math subjects, by location

\begin{tabular}{lcccc}
\hline & $\begin{array}{c}\text { Metropolitan } \\
\text { schools } \\
\text { N=352 }\end{array}$ & $\begin{array}{c}\text { Inner } \\
\text { regional } \\
\text { schools } \\
\mathbf{N = 1 1 4}\end{array}$ & $\begin{array}{c}\text { Outer } \\
\text { regional / } \\
\text { remote } \\
\text { schools } \\
\mathbf{N = 5 4}\end{array}$ & $\begin{array}{c}\text { All } \\
\text { schools } \\
\mathbf{N = 5 2 0}\end{array}$ \\
\hline Biology & $97 \%$ & $97 \%$ & $100 \%$ & $97 \%$ \\
Chemistry & $96 \%$ & $95 \%$ & $85 \%$ & $95 \%$ \\
Physics & $95 \%$ & $89 \%$ & $85 \%$ & $93 \%$ \\
Specialist maths & $71 \%$ & $48 \%$ & $22 \%$ & $61 \%$ \\
& & & & \\
4 subjects & $69 \%$ & $47 \%$ & $22 \%$ & $60 \%$ \\
3 subjects & $26 \%$ & $39 \%$ & $52 \%$ & $31 \%$ \\
2 subjects & $3 \%$ & $10 \%$ & $22 \%$ & $6 \%$ \\
1 subject & $1.4 \%$ & $4 \%$ & $4 \%$ & $2.3 \%$ \\
0 subject & $1.4 \%$ & $0 \%$ & $0 \%$ & $1.4 \%$ \\
\hline
\end{tabular}

In our next analysis, we examined in more fine-grained detail the characteristics of schools that offer all four subjects. These results are shown in Table 4. Large disparities are seen between all three locations, school SES quintiles, and school sectors.

Among metropolitan schools, $45 \%$ of low SES schools offer all four subjects, compared to $90 \%$ of high SES schools. This pattern is particularly pronounced for schools in the government and independent sectors. Overall, 64\% of public metropolitan schools offer all four subjects. The proportion of independent schools that offer all four subjects is similar, at only $69 \%$ of schools. Most high SES independent schools offer all four subjects, but the 
proportion is much smaller among lower SES independent schools. For Catholic schools, however, a clear pattern among school SES and access to all four subjects is not clear. On average, $84 \%$ of Catholic schools offer all four subjects. Interesting, the highest proportion is seen in low SES Catholic schools; all seven of the low SES Catholic schools offer all four subjects. Of the three sectors, Catholic schools are the most likely to offer all four subjects (84\%), with only $69 \%$ of independent and $64 \%$ of public schools offering all four subjects.

(continued on following page) 
Table 4. Number and proportion of schools offering all four science and maths subjects, by school SES, location and sector

\begin{tabular}{|c|c|c|c|c|c|}
\hline $\begin{array}{c}\text { Metrop } \\
\text { olitan }\end{array}$ & $\begin{array}{c}\text { School } \\
\text { SES } \\
\text { quintile }\end{array}$ & Gov & Cath & Ind & Total \\
\hline & 1 & $\begin{array}{c}25 \text { of } 61 \text { schools } \\
(41 \%)\end{array}$ & $\begin{array}{c}7 \text { of } 7 \text { schools } \\
(100 \%)\end{array}$ & $\begin{array}{c}0 \text { of } 3 \text { schools } \\
(0 \%)\end{array}$ & $\begin{array}{c}32 \text { of } 71 \text { schools } \\
(45 \%)\end{array}$ \\
\hline & 2 & $\begin{array}{c}37 \text { of } 53 \text { schools } \\
(70 \%)\end{array}$ & $\begin{array}{c}5 \text { of } 8 \text { schools } \\
(63 \%)\end{array}$ & $\begin{array}{c}5 \text { of } 9 \text { schools } \\
(56 \%)\end{array}$ & $\begin{array}{c}47 \text { of } 70 \text { schools } \\
(67 \%)\end{array}$ \\
\hline & 3 & $\begin{array}{c}19 \text { of } 23 \text { schools } \\
(83 \%)\end{array}$ & $\begin{array}{c}18 \text { of } 22 \text { schools } \\
(82 \%)\end{array}$ & $\begin{array}{c}8 \text { of } 25 \text { schools } \\
(32 \%)\end{array}$ & $\begin{array}{c}45(46) \text { of } 70 \\
\text { schools }(64 \%)\end{array}$ \\
\hline & 4 & $\begin{array}{c}20 \text { of } 24 \text { schools } \\
(83 \%)\end{array}$ & $\begin{array}{c}16 \text { of } 17 \text { schools } \\
(94 \%)\end{array}$ & $\begin{array}{c}19 \text { of } 29 \text { schools } \\
(66 \%)\end{array}$ & $\begin{array}{c}55 \text { of } 70 \text { schools } \\
(79 \%)\end{array}$ \\
\hline & 5 & $\begin{array}{c}8 \text { of } 9 \text { schools } \\
(89 \%)\end{array}$ & $\begin{array}{c}5 \text { of } 7 \text { schools } \\
(71 \%)\end{array}$ & $\begin{array}{c}51 \text { of } 55 \text { schools } \\
(93 \%)\end{array}$ & $\begin{array}{c}64 \text { of } 71 \text { schools } \\
(90 \%)\end{array}$ \\
\hline \multicolumn{2}{|l|}{ Total } & $\begin{array}{c}109 \text { of } 170 \\
\text { schools }(64 \%)\end{array}$ & $\begin{array}{c}51 \text { of } 61 \text { schools } \\
(84 \%)\end{array}$ & $\begin{array}{c}83 \text { of } 121 \text { schools } \\
(69 \%)\end{array}$ & $\begin{array}{c}243 \text { of } 352 \\
\text { schools }(69 \%)\end{array}$ \\
\hline \multirow[t]{6}{*}{$\begin{array}{l}\text { Inner } \\
\text { regional }\end{array}$} & $\begin{array}{c}\text { School } \\
\text { SES } \\
\text { quintile }\end{array}$ & Gov & Cath & Ind & Total \\
\hline & 1 & $\begin{array}{c}2 \text { of } 22 \text { schools } \\
(9 \%)\end{array}$ & $\begin{array}{c}1 \text { of } 1 \text { school } \\
(100 \%)\end{array}$ & NA & $\begin{array}{c}3 \text { of } 23 \text { schools } \\
(13 \%)\end{array}$ \\
\hline & 2 & $\begin{array}{c}12 \text { of } 23 \text { schools } \\
(52 \%)\end{array}$ & NA & NA & $\begin{array}{c}12 \text { of } 22 \text { schools } \\
(53 \%)\end{array}$ \\
\hline & 3 & $\begin{array}{c}9 \text { of } 18 \text { schools } \\
(50 \%)\end{array}$ & $\begin{array}{c}3 \text { of } 5 \text { schools } \\
(60 \%)\end{array}$ & NA & $\begin{array}{c}12 \text { of } 23 \text { schools } \\
(53 \%)\end{array}$ \\
\hline & 4 & $\begin{array}{c}1 \text { of } 5 \text { schools } \\
(20 \%)\end{array}$ & $\begin{array}{c}8 \text { of } 13 \text { schools } \\
(62 \%)\end{array}$ & $\begin{array}{c}2 \text { of } 5 \text { schools } \\
(40 \%)\end{array}$ & $\begin{array}{c}11 \text { of } 23 \text { schools } \\
(48 \%)\end{array}$ \\
\hline & 5 & $\begin{array}{c}0 \text { of } 1 \text { school } \\
(0 \%)\end{array}$ & $\begin{array}{c}5 \text { of } 6 \text { schools } \\
(83 \%)\end{array}$ & $\begin{array}{c}11 \text { of } 16 \text { schools } \\
(69 \%)\end{array}$ & $\begin{array}{c}16 \text { of } 23 \text { schools } \\
(70 \%)\end{array}$ \\
\hline Total & & $\begin{array}{c}24 \text { of } 68 \text { schools } \\
(35 \%)\end{array}$ & $\begin{array}{c}17 \text { of } 25 \text { schools } \\
(68 \%)\end{array}$ & $\begin{array}{c}13 \text { of } 21 \text { schools } \\
(62 \%)\end{array}$ & $\begin{array}{c}54 \text { of } 114 \text { schools } \\
(47 \%)\end{array}$ \\
\hline \multirow[t]{6}{*}{$\begin{array}{c}\text { Outer } \\
\text { regional } \\
\text { / remote } \\
\end{array}$} & $\begin{array}{c}\text { School } \\
\text { SES } \\
\text { quintile }\end{array}$ & Gov & Cath & Ind & Total \\
\hline & 1 & $\begin{array}{c}1 \text { of } 11 \text { schools } \\
(9 \%)\end{array}$ & NA & NA & $\begin{array}{c}1 \text { of } 11 \text { schools } \\
(9 \%)\end{array}$ \\
\hline & 2 & $\begin{array}{c}4 \text { of } 10 \text { schools } \\
(40 \%)\end{array}$ & $\begin{array}{c}1 \text { of } 1 \text { school } \\
(100 \%)\end{array}$ & NA & $\begin{array}{c}5 \text { of } 11 \text { schools } \\
(45 \%)\end{array}$ \\
\hline & 3 & $\begin{array}{c}1 \text { of } 10 \text { schools } \\
(10 \%)\end{array}$ & NA & NA & $\begin{array}{c}1 \text { of } 10 \text { schools } \\
(10 \%)\end{array}$ \\
\hline & 4 & $\begin{array}{c}2 \text { of } 10 \text { schools } \\
(20 \%)\end{array}$ & $\begin{array}{c}0 \text { of } 1 \text { school } \\
(0 \%)\end{array}$ & NA & $\begin{array}{c}2 \text { of } 11 \text { schools } \\
(18 \%)\end{array}$ \\
\hline & 5 & $\begin{array}{c}1 \text { of } 7 \text { schools } \\
(14 \%)\end{array}$ & $\begin{array}{c}2 \text { of } 2 \text { schools } \\
(100 \%)\end{array}$ & $\begin{array}{c}0 \text { of } 2 \text { schools } \\
(0 \%)\end{array}$ & $\begin{array}{c}3 \text { of } 11 \text { schools } \\
(27 \%)\end{array}$ \\
\hline Total & & $\begin{array}{c}9 \text { of } 48 \text { schools } \\
(19 \%)\end{array}$ & $\begin{array}{c}3 \text { of } 4 \text { schools } \\
(75 \%)\end{array}$ & $\begin{array}{c}0 \text { of } 2 \text { schools } \\
(0 \%)\end{array}$ & $\begin{array}{c}12 \text { of } 54 \text { schools } \\
(22 \%)\end{array}$ \\
\hline
\end{tabular}

Among inner regional schools, only $13 \%$ of low SES schools offer all four subjects, compared to $70 \%$ of high SES schools as shown in Table 4 . In terms of sector, $35 \%$ of public schools, $68 \%$ of Catholic schools and $62 \%$ of independent schools offer all four subjects. These findings suggest that access to science and maths subjects is far from universal in inner regional communities. It also suggests that in many communities, access to these subjects is 
only achieved by paying fees to attend a non-government school. This finding is even more striking in outer regional communities, where access to all science and math subjects is only available in 19\% of government schools and $9 \%$ of low SES schools (all of which are in the government sector). Overall, only $22 \%$ of schools in outer regional communities offer all four subjects.

Lastly, we examined in closer detail access to Specialist Mathematics (Table 5) since it is the least likely to be offered by schools. Access to this subject is far from universal and large disparities are found between school locations, sectors and SES quintiles. For example, 95\% of high SES metropolitan independent schools offer Specialist Maths, compared to 9\% of low SES inner or outer regional government schools.

(continued on following page) 
Table 5. Schools that offer Specialist Maths

\begin{tabular}{|c|c|c|c|c|}
\hline \multicolumn{5}{|c|}{ Metropolitan } \\
\hline $\begin{array}{l}\text { Scnoor SES } \\
\text { quintile }\end{array}$ & Gov & Cath & Ind & Total \\
\hline ב & $\begin{array}{c}25 \text { of } 61 \text { schools } \\
(41 \%)\end{array}$ & $\begin{array}{c}7 \text { of } 7 \text { schools } \\
(100 \%)\end{array}$ & $\begin{array}{c}0 \text { of } 3 \text { schools } \\
(0 \%)\end{array}$ & $\begin{array}{c}32 \text { of } 71 \text { schools } \\
(45 \%)\end{array}$ \\
\hline 2 & $\begin{array}{c}37 \text { of } 53 \text { schools } \\
(70 \%)\end{array}$ & $\begin{array}{c}6 \text { of } 8 \text { schools } \\
(75 \%)\end{array}$ & $\begin{array}{c}6 \text { of } 9 \text { schools } \\
(67 \%)\end{array}$ & $\begin{array}{c}49 \text { of } 70 \text { schools } \\
(70 \%)\end{array}$ \\
\hline 3 & $\begin{array}{c}20 \text { of } 23 \text { schools } \\
(87 \%)\end{array}$ & $\begin{array}{c}19 \text { of } 22 \text { schools } \\
(86 \%)\end{array}$ & $\begin{array}{c}9 \text { of } 25 \text { schools } \\
(36 \%)\end{array}$ & $\begin{array}{c}48 \text { of } 70 \text { schools } \\
(69 \%)\end{array}$ \\
\hline 4 & $\begin{array}{c}20 \text { of } 24 \text { schools } \\
(83 \%)\end{array}$ & $\begin{array}{c}16 \text { of } 17 \text { schools } \\
(94 \%)\end{array}$ & $\begin{array}{c}21 \text { of } 29 \text { schools } \\
(72 \%)\end{array}$ & $\begin{array}{c}57 \text { of } 70 \text { schools } \\
(81 \%)\end{array}$ \\
\hline 5 & $\begin{array}{c}8 \text { of } 9 \text { schools } \\
(89 \%)\end{array}$ & $\begin{array}{c}5 \text { of } 7 \text { schools } \\
(86 \%)\end{array}$ & $\begin{array}{c}52 \text { of } 55 \text { schools } \\
(95 \%)\end{array}$ & $\begin{array}{c}65 \text { of } 71 \text { schools } \\
(92 \%)\end{array}$ \\
\hline Total & $\begin{array}{c}110 \text { of } 170 \text { schools } \\
(65 \%)\end{array}$ & $\begin{array}{c}53 \text { of } 61 \text { schools } \\
(87 \%)\end{array}$ & $\begin{array}{c}88 \text { of } 121 \text { schools } \\
(73 \%)\end{array}$ & $\begin{array}{c}251 \text { of } 352 \text { schools } \\
(71 \%)\end{array}$ \\
\hline \multicolumn{5}{|c|}{ Inner Regional } \\
\hline $\begin{array}{c}\text { School SES } \\
\text { quintile }\end{array}$ & Gov & Cath & Ind & Total \\
\hline$x$ & $\begin{array}{c}2 \text { of } 22 \text { schools } \\
(9 \%)\end{array}$ & $\begin{array}{c}1 \text { of } 1 \text { school } \\
(100 \%)\end{array}$ & NA & $\begin{array}{c}3 \text { of } 23 \text { schools } \\
(13 \%)\end{array}$ \\
\hline 2 & $\begin{array}{c}12 \text { of } 22 \text { schools } \\
(55 \%)\end{array}$ & NA & NA & $\begin{array}{c}12 \text { of } 22 \text { schools } \\
(55 \%)\end{array}$ \\
\hline 3 & $\begin{array}{c}9 \text { of } 18 \text { schools } \\
(50 \%)\end{array}$ & $\begin{array}{c}3 \text { of } 5 \text { schools } \\
(60 \%)\end{array}$ & NA & $\begin{array}{c}12 \text { of } 23 \text { schools } \\
(52 \%)\end{array}$ \\
\hline 4 & $\begin{array}{c}1 \text { of } 5 \text { schools } \\
(20 \%)\end{array}$ & $\begin{array}{c}8 \text { of } 13 \text { schools } \\
(62 \%)\end{array}$ & $\begin{array}{c}2 \text { of } 5 \text { schools } \\
(40 \%)\end{array}$ & $\begin{array}{c}11 \text { of } 23 \text { schools } \\
(48 \%)\end{array}$ \\
\hline 5 & $\begin{array}{c}0 \text { of } 1 \text { school } \\
(0 \%)\end{array}$ & $\begin{array}{c}5 \text { of } 6 \text { schools } \\
(83 \%)\end{array}$ & $\begin{array}{c}12 \text { of } 16 \text { schools } \\
(75 \%)\end{array}$ & $\begin{array}{c}17 \text { of } 23 \text { schools } \\
(74 \%)\end{array}$ \\
\hline Total & $\begin{array}{c}24 \text { of } 68 \text { schools } \\
(35 \%)\end{array}$ & $\begin{array}{c}17 \text { of } 25 \text { schools } \\
(68 \%)\end{array}$ & $\begin{array}{c}14 \text { of } 21 \text { schools } \\
(67 \%)\end{array}$ & $\begin{array}{c}55 \text { of } 114 \\
(48 \%) \\
\end{array}$ \\
\hline \multicolumn{5}{|c|}{ Outer Regional / Remote } \\
\hline $\begin{array}{c}\text { School SES } \\
\text { quintile }\end{array}$ & Gov & Cath & Ind & Total \\
\hline$x_{0}$ & $\begin{array}{c}1 \text { of } 11 \text { schools } \\
(9 \%)\end{array}$ & NA & NA & $\begin{array}{c}1 \text { of } 11 \text { schools } \\
(9 \%)\end{array}$ \\
\hline 2 & $\begin{array}{c}4 \text { of } 10 \text { schools } \\
(40 \%)\end{array}$ & $\begin{array}{c}1 \text { of } 1 \text { school } \\
(100 \%)\end{array}$ & NA & $\begin{array}{c}5 \text { of } 11 \text { schools } \\
(45 \%)\end{array}$ \\
\hline 3 & $\begin{array}{c}1 \text { of } 10 \text { schools } \\
(10 \%)\end{array}$ & NA & NA & $\begin{array}{c}1 \text { of } 10 \text { schools } \\
(10 \%)\end{array}$ \\
\hline 4 & $\begin{array}{c}2 \text { of } 10 \text { schools } \\
(20 \%)\end{array}$ & $\begin{array}{c}0 \text { of } 1 \text { school } \\
(0 \%)\end{array}$ & NA & $\begin{array}{c}2 \text { of } 11 \text { schools } \\
(18 \%)\end{array}$ \\
\hline 5 & $\begin{array}{c}1 \text { of } 7 \text { schools } \\
(14 \%)\end{array}$ & $\begin{array}{c}2 \text { of } 2 \text { schools } \\
(100 \%)\end{array}$ & $\begin{array}{c}0 \text { of } 2 \text { schools } \\
(0 \%)\end{array}$ & $\begin{array}{c}3 \text { of } 11 \text { schools } \\
(27 \%)\end{array}$ \\
\hline Total & $\begin{array}{c}9 \text { of } 48 \text { schools } \\
(19 \%)\end{array}$ & $\begin{array}{c}3 \text { of } 4 \text { schools } \\
(75 \%)\end{array}$ & $\begin{array}{c}0 \text { of } 2 \text { schools } \\
(0 \%)\end{array}$ & $\begin{array}{c}12 \text { of } 54 \\
(22 \%)\end{array}$ \\
\hline
\end{tabular}

In summary, the descriptive analyses show varying degrees of access to the four science and math subjects. Biology and Chemistry are almost universally offered, and 
Physics is widely offered. Access to Specialist Maths, however, is very restricted in some school contexts and is particularly limited in non-metropolitan schools.

Next we report the results of the logistic regression. There were no violations to the assumption of linearity in the logit (Box-Tidwell test). The likelihood ratio test indicated that the model performed significantly better than the intercept only model $\left(\chi^{2}(6)=223, p<\right.$ $.001)$. The Hosmer and Lemeshow goodness of fit test showed no evidence of poor fit $\left(\chi^{2}(8)\right.$ $=6.90, p=0.548)$, and McFadden's pseudo $\mathrm{R}^{2}$ indicated good fit $\left(\mathrm{R}^{2}=0.325\right)$. We report the log odds and odds ratios for each independent variable.

Table 6: Log Odds and Odds Ratios

\begin{tabular}{lcc}
\cline { 2 - 3 } & Log Odds & Odds Ratio \\
\hline (intercept) & -13.95 & NA \\
sector - independent & 0.3480 & 1.4163 \\
sector - catholic & 0.7783 & 2.1778 \\
location - inner regional & 0.0212 & 1.0214 \\
location - outer regional & -0.7601 & 0.4676 \\
ICSEA & 0.0123 & 1.0123 \\
school size & 0.0170 & 1.0171 \\
\hline
\end{tabular}

From Table 6, we can see that the Catholic and independent sectors were associated with increased odds of offering Specialist Mathematics compared to government schools. The Catholic school effect was stronger than independent schools. Inner regional schools had similar odds to metropolitan schools of offering Specialist Mathematics, whilst outer regional area was associated with reduced odds. In addition, increases in ICSEA and school size were associated with increased odds of a school offering Specialist Mathematics. Controlling for all other variables in the model, the odds of an outer regional school offering Specialist Mathematics were 0.4676 of that of a metropolitan school (53.24\% reduced odds). With a one point increase in ICSEA, the odds of a school offering Specialist Mathematics increased by a factor of 1.0123 (1.23\% increase in odds per point). This is a very substantial increase as 
the range of ICSEA scores in our population spanned approximately 350 points. To illustrate, the odds ratio for a 100 point increase in ICSEA is 3.42 .

\section{Discussion}

Our analysis has uncovered substantial between-school inequalities in access to science and math subjects. While most secondary schools offer biology and chemistry, opportunities to learn physics are not available in some schools and advanced mathematics is even less accessible. In some contexts, opportunities to learn can be severely constricted, especially for advanced mathematics, a core subject for any science-based university degree. These inequalities are particularly pronounced among regional schools and low SES metropolitan schools. School size, school socioeconomic composition, school location and school sector all have independent effects on the likelihood of a school offering advanced mathematics. Our findings suggest that powerful structural inequalities are shaping students' opportunity to learn science and math subjects in upper secondary school.

Critics may query whether limited access to science and math curricula is a problem if there are no students at a given school who are interested in these subjects. Our response is that student "demand" does not exist in a vacuum but is rather shaped by naturalised constructions of what is appropriate and normal for particular groups of students. When these naturalised constructions are patterned by group characteristics such as gender, ethnicity, or social class, they become educational inequalities rather than individual dispositions.

Disrupting these notions of what is appropriate for particular students, based on their place of residence and social background, is necessary for reducing educational inequalities.

In this section we provide some possible explanations for our findings, drawing on the literature and our depiction of the organizational features of the Australian educational context for insight. 
At the most basic level, science and math curricular offerings vary between schools because of the decentralisation of curricular decision making. As described earlier, schools in Australia are given autonomy to choose which curricular subjects to offer in the final two years of secondary school. This autonomy in turn is conditioned by other factors which explain why some schools offer particular curricular subjects, such as advanced mathematics, and other schools do not. In Australia, the factors that influence school curricular decisions are student demand, school funding and resources including teaching staff, and school strategies for maintaining or increasing their profile and share in the local education market (Perry \& Lubienski, 2020). In several countries, student demand is related to curricular offerings (Marginson et al., 2013), and student demand as a dynamic force shaped by other factors such as school marketing (Lubienski, 2007). School resources have also been noted in the literature. Constrained curricular offerings due to insufficient resources appears to be more common in the US compared to other countries, or at least has received more attention from researchers. This is not surprising given the very large funding inequalities documented by Berliner (2014) that exist between public schools in the US.

Unlike the US, large funding inequalities do not exist between Australian public schools (but they do exist between many private and public schools). Nevertheless, funding models in Australia make it difficult for some schools to offer a wide range of subjects, especially in view of school size and socioeconomic composition. Schools receive funding based on the number of pupils they enrol, and are given the autonomy to hire staff and make curricular decisions as they see fit and within their budget. Offering a curricular subject with low student numbers (typically less than 15 students) is economically unviable but some schools will nevertheless accept the cost as a strategic investment because they seek to maintain their profile and status in the educational marketplace (Perry \& Lubienski, 2020). Well-resourced schools are particularly well placed and incentivized to make the strategic 
investment to offer advanced mathematics (for example) to a small number of students. Thus, even though large funding inequalities do not exist between public schools in Australia, the marketised underpinnings of the funding model as well as the larger marketised context in which schools operate and compete for students creates resource constraints for many schools. Smaller schools, schools that are hard to staff, and schools with lower socioeconomic compositions - features that frequently come together - face difficulties in offering a wide range of curricular subjects, especially those that are considered academically rigorous, such as advanced mathematics. This is because they have less overall funding and smaller staff numbers because of their smaller enrolment size, and their lower socioeconomic compositions mean they typically experience lower student demand for rigorous academic subjects, more difficulty recruiting and retaining qualified staff, and additional funding demands for support services (Roberts, 2016). While such schools receive supplementary funding and staffing entitlements to be able to offer a broader curriculum than may otherwise be possible with student numbers, and are increasingly offering online subject offerings in lieu of face to face delivery, our results suggest that they do not mediate subject availability significantly.

Student interest in science and math subjects is influenced by curricular policy frameworks and practices. First, the tradition in Australia (and the UK and many other countries with comprehensive education systems) of subject specialisation in upper secondary school may reduce widespread participation in science and math subjects. Rather than study a broad range of curricular subjects, as is common in the US, Australian students are encouraged to choose subjects based on their interest and aptitude. For many students, this means mostly STEM or mostly humanities subjects. Second, Australia's use of externally assessed, subject-specific examinations as a basis for secondary school completion and university admittance may create additional barriers for universal access to science and math 
subjects. External examinations are linked with decreased student interest in science and math careers, and by association, interest in studying science and math subjects in secondary school (Han, 2016). Third, the large range of externally assessed curricular subjects makes it inevitable that some subjects will not be offered. It also increases opportunities for students to be drawn to other subjects (Kennedy et al., 2014; Marginson et al., 2013).

Our finding that Catholic schools, regardless of their socioeconomic composition, provide widespread access to science and math subjects is consistent with studies conducted in the US. It may be that Catholic schools are committed to offering "core" curricular subjects as part of their Catholic ethos and mission, as has been suggested for Catholic schools in the US by Lee et al. (1998). It is also possible that low SES Catholic schools are better placed to offer these subjects than public schools with similar compositions because of parental expectations and student demand. Given the limited access to advanced mathematics in low SES public schools, for example, it is plausible that Catholic schools provide the only opportunity to study science and math subjects in many working-class communities. Families with aspirations for STEM careers and perhaps university study more generally may choose a Catholic school over the local public school in these working-class communities for the curricular advantages that the former provides. This in turn creates sufficient demand for science and math (and other traditional academic) curricular subjects, which makes it more sustainable for a school to resource and staff them. In this regard, Catholic schools' ability to offer science and math subjects may be linked to the lack of such offerings at nearby public schools; in other words, one school's loss is another school's gain. Testing this market-share hypothesis would warrant further study.

As access to science and math subjects is patterned by school social composition, it makes sense to consider the systemic features that may exacerbate social segregation between schools. As described earlier, Australian schooling has a number of features that may 
intensify the social segregation of schools. These include high levels of privatisation and school choice and competition. Access to science and math curricula is likely to be both a cause and a consequence of school segregation. Schools that do not offer advanced mathematics and physics may be less attractive for families that aspire to university study and science and math careers. As a consequence, such families may choose a different school in the educational marketplace, thereby contributing to the residualisation of the local public school. At the same time, residualised schools are less likely to be able to offer these science and math subjects due to low student demand and interest, thereby contributing to a vicious cycle.

In many rural/regional communities and urban working class communities, access to science and math curricula requires families to pay for private schooling. For rural students, this may even mean boarding away from home, a practice that has been common in Australia among affluent farming families for decades. Limited curricular choices in upper secondary school has a number of negative consequences for rural communities. As uncovered in their study of over 3,000 participants, Stokes et al. (2000) showed that limited curricular offerings drive some educationally aspirational families to leave the local school or even the rural community, with negative consequences for the students and community members left behind.

\section{Towards a theoretical framework}

One of our aims is to use our findings from Australia as a first step in the development of a theoretical framework about the factors that shape stratified curricular access in comprehensive education systems. We hope that our framework can guide future comparative research about stratified access to curricular subjects in range of national contexts. Comparative research is particularly useful for generating theory about the 
conditions and contexts that explain a particular educational phenomenon or outcome. As research about curricular access is conducted in other countries, we anticipate that the theoretical framework will be refined and elaborated, leading to a greater understanding of the contexts, characteristics, practices and policies of schools and education systems that explain stratified curricular access.

Figure 1: Theoretical framework of factors that shape stratified between-school curricular access in comprehensive education systems

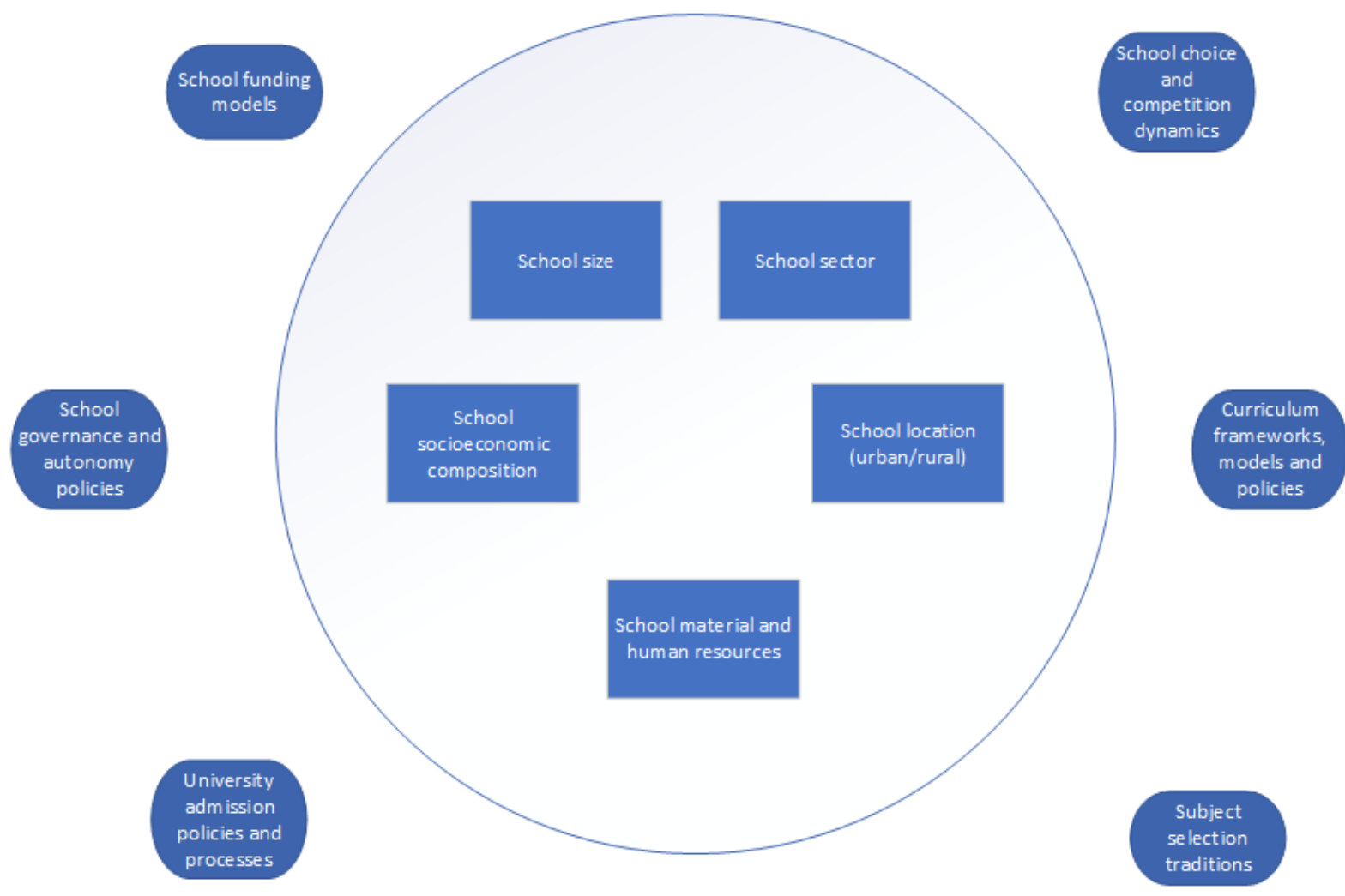

Figure 1 shows two interlocking categories of factors that shape curricular access: characteristics of schools, represented in the inner circle with the rectangular shaped blocks, and factors from the larger social and educational context, represented by oval shaped blocks situated outside the circle. School characteristics are factors that directly impact a school's curricular offerings. The degree to which these factors shape curricular access is likely to vary cross-nationally, with some factors more important in some contexts than in others. 
Moreover, it is likely that these school characteristics are interrelated in complex ways (e.g., school funding is related to school composition and school sector), and that these complex relations also vary by national context (e.g., school funding is related to school sector in only some countries). In addition to school characteristics, factors from the larger educational and social context may shape curricular access. These include education policies and organizational features of schooling (e.g., how schools are funded, how students are sorted into schools, the decision-making powers granted to schools), historical traditions (e.g., whether students are expected to study a broad or narrow range of subjects), university admission practices, and curricular frameworks and policies (e.g., whether curricular subjects are standardised and/or externally assessed).

\section{Conclusion}

While not all students have the interest or motivation to study science and math subjects, we argue that all students should have the opportunity to study them. It is neither fair nor efficient to base an innovation agenda on an education system that provides access to science and math curricula based on one's ability to pay for private schooling or reside within the catchment zone of a metropolitan middle-class public school. Ensuring this educational right does not mean that every school must offer every science and math curricular subject, but it does mean that every student should be guaranteed free access to it.

Researchers have examined the reasons why student participation in science and math offerings in secondary school and beyond is stagnant or even declining in many countries. Most researchers have focused on student-related factors that shape science and math participation in secondary school. A main contribution of our paper is to show that structural inequalities also underlie participation rates in science and math curricula. It is difficult to increase science and math participation rates if schools do not offer these subjects. Thus, 
efforts to increase science and math participation should address structural inequalities in students' opportunities to study science and math subjects, as well as attempt to increase students' motivation and interest. Our findings from Australia may offer insights for other countries with similar education policies and contexts, as well as for countries that are embracing school choice and competition.

\section{Declaration of interest statement}

The authors report there are no competing interests to declare.

\section{References}

ACARA. (n.d.). Specialist mathematics: Rationale. https://www.australiancurriculum.edu.au/senior-secondarycurriculum/mathematics/specialist-mathematics/rationale/

Adelman, C. (2006). The toolbox revisited: Paths to degree completion from high school through college. US Department of Education.

Anderson, R., \& Chang, B. (2011). Mathematics course-taking in rural high schools. Journal of Research in Rural Education, 26(1), 1-10.

Archer, L., Moote, J., Francis, B., DeWitt, J., \& Yeomans, L. (2017). Stratifying science: A Bourdieusian analysis of student views and experiences of school selective practices in relation to 'triple science' at KS4 in England. Research Papers in Education, 32(3), 296-315.

Australian Bureau of Statistics (2018). 4221.0 - Schools, Australia, 2017. Summary Table $80 \mathrm{a}$.

https://www.abs.gov.au/AUSSTATS/abs@.nsf/DetailsPage/4221.02017?OpenDocum ent

Barrington, F. (2011). AMSI interim update on Year 12 mathematics student numbers. Melbourne: Australian Mathematical Sciences Institute.

Berliner, D. C. (2014). Effects of inequality and poverty vs. teachers and schooling on America's youth. Teachers College Record, 116(1), http://www.tcrecord.org/Content.asp?ContentId=16889. 
Chmielewski, A. K. (2014). An international comparison of achievement inequality in within-and between-school tracking systems. American Journal of Education, 120(3), 293-324.

Connors, L., \& McMorrow, J. (2015). Imperatives in schools funding: Equity, sustainability and achievement. Australian Council for Educational Research.

Drury, C., \& Allen, A. (2002). Task force on the physical sciences---report and recommendations. Department of Education and Science (Ireland).

Goodrum, D., Druhan, A., \& Abbs, J. (2012). The status and quality of Year 11 and 12 science in Australian schools. Australian Academy of Science.

Human Rights and Equal Opportunity Commission (HREOC). (2000). Emerging Themes. National Inquiry into Rural and Remote Education. Commonwealth of Australia.

Jones, M. G., Howe, A., \& Rua, M. J. (2000). Gender differences in students' experiences, interests, and attitudes toward science and scientists. Science Education, 84, 180-192.

Jørgensen, B. C. (1998). Mathematics and physics education in society - the justification and enrolment problems from a general perspective. In J. H. Jensen, M. Niss \& T. Wedege (Eds.), Justification and enrolment problems in education involving mathematics or physics. Roskilde University Press.

Kennedy, J., Lyons, T., \& Quinn, F. (2014). The continuing decline of science and mathematics enrolments in Australian high schools. Teaching Science, 60(2), 34-46.

Lamb, S., \& Fullarton, S. (2002). Classroom and school factors affecting mathematics achievement: A comparative study of Australia and the United States using TIMSS. Australian Journal of Education, 46(2), 154-173.

Lee, V. E., Chow-Hoy, T. K., Burkam, D. T., Geverdt, D., \& Smerdon, B. A. (1998). Sector differences in high school course taking: A private school or Catholic school effect? Sociology of Education, 71(4), 314-335.

Lubienski, C. (2007). School competition and the emergence of symbolism in a market environment. In C. F. Kaestle and A. E. Lodewick (Eds.), To educate a nation: Federal and national strategies of school reform (pp. 257-280). University Press of Kansas.

Marginson, S., Tytler, R., Freeman, B., \& Roberts, K. (2013). STEM: Country comparisons: International comparisons of science, technology, engineering and mathematics (STEM) education. Final report. Australian Council of Learned Academies.

National Research Council. (2010). Rising above the gathering storm, revisited: Rapidly rising to category 5 . Author. 
Oakes, J. (2005). Keeping track: How schools structure inequality (2nd edition). Yale University Press.

OECD. (2019). PISA 2018 results: Combined executive summaries (volume I, II \& III). Paris: Author.

Perry, L. B., \& Lubienski, C. (2020). Between-school stratification of academic curricular offerings in upper secondary education: School decision-making, curriculum policy context, and the educational marketplace. Oxford Review of Education, 46(5), 582600.

Perry, L. B., \& Southwell, L. (2014). Access to academic curriculum in Australian secondary schools: A case study of a highly marketised education system. Journal of Education Policy, 29(4), 467-485.

Roberts, P. (2016). Place, rural education and social justice: A study of rural teaching and curriculum politics [Unpubished doctoral dissertation]. Charles Sturt University.

Sadler, P. M., Sonnert, G., Hazari, Z., \& Tai, R. (2012). Stability and volatility of STEM career interest in high school: A gender study. Science Education, 96(3), 411-427.

Smith, E. (2011). Staying in the science stream: Patterns of participation in a-level science subjects in the UK. Educational Studies, 37(1), 59-71.

Smyth, E., \& Hannan, C. (2006). School effects and subject choice: The uptake of scientific subjects in Ireland. School Effectiveness and School Improvement, 17(3), 303-327.

Stokes, H., Stafford, J., \& Holdsworth, R. (2000). Rural and remote school education: A survey for the Human Rights and Equal Opportunity Commission. University of Melbourne.

Svoboda, R. C., Rozek, C. S., Hyde, J. S., Harackiewicz, J. M., \& Destin, M. (2016). Understanding the relationship between parental education and STEM course taking through identity-based and expectancy-value theories of motivation. AERA Open, 2(3), 2332858416664875.

Teese, R., \& Lamb, S. (2007). Social inequalities in education: Enlarging the scope of public policy through reflection on context. In R. Teese, S. Lamb \& M. Duru-Bellat (Eds.), International studies in educational inequality, theory and policy (Vol. 3, pp. 293308). Springer.

Wang, M.-T., \& Degol, J. (2013). Motivational pathways to STEM career choices: Using expectancy-value perspective to understand individual and gender differences in STEM fields. Developmental Review, 33(4), 304-340. 
Watson, L., \& Ryan, C. (2010). Choosers and losers: The impact of government subsidies on Australian secondary schools. Australian Journal of Education, 54(1), 86-107. 